\title{
Research and practice on the construction of excellent resource sharing course for Crane Metallic Structure
}

\author{
Xiao Wu \\ School of Mechanical Engineering, \\ Southwest Jiaotong University, \\ Chengdu, China \\ e-mail: wuxiao@swjtu.edu.cn
}

\author{
Wenming Cheng \\ School of Mechanical Engineering, \\ Southwest Jiaotong University, \\ Chengdu, China \\ e-mail: wmcheng@swjtu.edu.cn
}

\author{
Lanfeng $\mathrm{Yu}$ \\ School of Mechanical Engineering, \\ Southwest Jiaotong University, \\ Chengdu, China \\ e-mail: jdlf2000@sohu.com
}

\begin{abstract}
The excellent resource sharing course construction aims at promoting the transformation of the concept of education and teaching, leading the reform of teaching content and teaching methods, driving colleges and universities excellent resource through modern information technology to build and share, improving talents training quality and servicing to society. In this paper, the construction practice of excellent resource sharing course is illustrated on the base of National Great Courses, combined with the course of Metallic Structure which is the core professional courses of the Southwest Jiaotong University's mechanical major. A number of issues in the construction and practice of excellent resource sharing course are analyzed and demonstrated in the aspect of the course characteristic, teaching staff, course content, course resources, etc. The construction of excellent resource sharing courses Metallic Structure is discussed according to the characteristics of course and the training requirements of mechanical talents.
\end{abstract}

Keywords- higher engineering education, excellent resource sharing course, Metallic Structure, construction of course, practice

\section{INTRODUCTION}

The Metallic Structure course comprehensively applies the basic theories and methods of theoretical mechanics, material mechanics, and structural mechanics to solve the calculation and the analysis of the large mechanical equipment structure design, which is one of core professional courses for the mayor of Mechanical Design, Manufacture and Automation in Southwest Jiaotong University's. This course has been taught by several well-known professors for nearly 60 years. After a long-term accumulation and heritage of history, the characteristics of this course which is aimed at the engineering design, settlement practical engineering problems has been formed so that the great impact is had in the domestic counterparts, and this course was named the national excellent course and had become demonstrative course in the counterparts in 2009.

Currently, on the basis of the achievements of the original National Great Courses construction, the Metallic Structure course is being constructed as the excellent resource sharing courses, under the support of the Ministry of Education's Colleges and Universities Undergraduate Teaching Quality and Teaching Reform Project. The excellent resource sharing courses construction is a part of the national the excellent open course construction project designed to promote the transformation of the concept of education and teaching, to lead the reform of teaching content and teaching methods, to drive colleges and universities excellent resource and to improve talents training quality and service to society. The excellent resource sharing course makes an enormous quantity of wide public basic courses, professional foundation courses and professional core courses as the key points, makes the course resources system, rich and suitable network communication as the basic requirements. After the construction of nation, province and school, the general undergraduate education, higher vocational education, network education and multitype multi-level of high quality teaching resources sharing system have been formed, which can provide the university teachers, students and social learners for high quality teaching resource.

The Metallic Structure course is the core professional course of the mechanical engineering undergraduate who will be engaged in structural design of machinery and equipment with first-class, excellent and sharing resource for course construction. Its goal is to construct demonstrative open courses with features of first-class teaching content, first-class teaching method, teaching material and teaching administration faced the college students and social learners under the support of information and network technology.

\section{CONSTRUCTION OF THE COURSE FEATURE}

A. Adhere to constructing the course system and compiling teaching material and reflecting course level and characteristics with excellent materials and works

In the long course of construction, the team has completed the course system construction of the content and improved the teaching content according to the development of new technology and talent training requirements continuously from 1960s. During the course construction and professional development process, the team has insisted on compiling the teaching material chronically, and so far, has accumulated translated and compiled more than 20 kinds teaching materials, atlas, and manual, in which Crane Design Manual compiled in 1998 is the only manual in the industry design, and has been widely used in all kinds of crane and engineering machinery design. From 2011 to 2012, the course team united more than 10 universities and 30 backbone enterprises completed new Crane Design Manual with nearly 4 million words. The course team insists on compiling the teaching material associated with the course all the while, in which the teaching material Crane Metallic 
Structure edited chiefly be us won the national excellent teaching material first prize. The writing excellent teaching material, design manual and related works is the outstanding characteristic of this course construction, and is one of the most important works that should be continued to adhere in the future as well.

\section{B. Adhere to carrying out scientific research related with} the course content to improve the level of research and to drive teaching and academic level as the reflection of the course features

Combined with the course content, the course teaching team has carried out scientific research based on the need of the modernization in mechanical equipment. Since the 1970s, it has presided numerous projects about Metallic Structure closely related to national, provincial scientific research task, and has achieved a large number of innovative research results and obtained more than 30 national and provincial awards. The subject leaders and famous scholars have been emerged in this term in every period. It has promoted the whole team academic level, the improvement of teaching quality and the development of the teaching by a high level of scientific research. The high academic level has become another reflection of the course feature.

\section{Integrate and apply various resources to serve the course teaching}

For the professional course, students should not only master theory expertly, but also have the ability to solve practical engineering problems. Based on reasonably integrating long-term accumulated all kinds of resources, such as scientific research resources, engineering projects, enterprise resources and lab resources, the course teaching team formed a series of high quality resources to serve the teaching, which includes: the product design, scientific research, the production practice. Finally, students can be directly involved in teachers' scientific research projects, such as the engineering design projects, enterprise practice, what's more, they can finish their graduation design together with the enterprise projects. Students can be directly involved in teachers' scientific research projects, such as engineering design projects, the enterprise practice, combining enterprise project graduation design with the learning process. During Students' learning period, they have many opportunities to meet the practical engineering problems, which is effectively for them to master the methods of solving practical problems and improve their working abilities.

\section{CONSTRUCTION OF THE TEACHING TEAM}

\section{A. Take excellent talents as the core to construct the teacher team}

The teaching staff of the excellent course should not only have reasonable teacher structure and knowledge structure, but also own the core member who led the team to move forward. In particular, the teaching staff should have a core teacher at least, who can be the leader of course building and the constructor of course system in different periods.
Meanwhile, teachers who have various teaching style and approve of the system are needed to enrich and develop the curriculum system.

Viewed from the period of constructing Metallic Structure in our school, we have the outstanding teaching team which aims to cultivate talents. In the first 20 years of major foundation and course construction, the professors, who studied in Soviet Union, led the teaching staff to develop major and courses with the completely blank conditions. In 1980s and 1990s, the National Expert with Remarkable Contributions improved and developed the courses perfectly and trained a number of excellent teachers. Currently, we formulate a teaching team with several opinion leaders as the core, which are composed of reasonable structure of degree, age and professional certificate and have abundant experience in teaching, research and engineering practice.

\section{B. Emphasize on scientific research to improve teachers' professional skill and promote the development of teaching}

Scientific research is an important approach to improve teacher's professional level and broaden their horizons. The course teaching team of the Metallic Structure adheres to promote the teaching by scientific research. Teaching team presided over numerous National and Provincial scientific research subject, and gained several national and provincial awards. Hundreds of academic papers were published in the domestic and foreign journals. To meet the need of the national economic construction, the teaching team cooperated with enterprises to develop a series of new products and gained the remarkable economic and social benefits. The insistence of scientific research effectively improved the academic level of the teachers, and then improved the teachers' teaching level, provided many excellent teachers for course construction and promoted the development of teaching.

\section{Cultivate young teachers actively, reserve teachers for the benign and sustainable development of the course}

The training of young teachers is an important link of building the team, it directly related to the sustainable development of high-quality sharing course construction. Therefore, they have taken various measures to train the young teachers in the process of course construction and teaching practice.

1) Formulate special training plans for young teachers. Combining with the need of course construction and scientific research, we formulated and carried out the plan of training for young teachers, making young teachers enhance the sense of responsibility and mission. Based on the teachers' actual conditions, we made the training plans, which can let them to develop their talent and make them outstanding.

2) Organize young teachers to attend teaching communication. With the support of special fund, we organized young teachers to take part in the lecture competitions and education teaching practice, so as to 
enhance young teachers' teaching level by learning from experts.

3) The job-training of young teachers. Before young teachers give the lectures, they should accomplish a series of training with the help of experienced teachers, which includes: making the syllabus, modifying teaching plan, arranging teaching demonstration, attending the comment on lecture. In order to help young teachers to adapt the teaching as soon as possible, we encourage young teachers to take part in related teaching reform project and teaching research subject, to write teaching research papers, and to participate in teaching material construction.

4) Actively organize young teachers attending external communication. Taking the needs of curriculum and scientific research into account, the teaching and research section selectively send young teachers to participate in college visit and communication at home and abroad. In the exchange meeting, they learn teaching experience and advanced education concept from each others, at the same time, it expends their academic perspective and strengthens their bilingual teaching ability.

\section{ESTABLISHMENT OF COURSE CONTENTS}

\section{A. According to the needs of Research University and innovative talent training, revising the course system and teaching contents}

1) Clarify the nature and positioning of the course. Metallic Structure is a foundation course to learn about the design of hoisting and conveying machinery. The main target is to help students master the traditional design methods. Further, doing the analysis with the use of modern design theory and method is an important mean to develop their ability.

2) Streamline course contents and highlight the key ones and new technical theory. On the basis of (A), the teaching and research section streamlines the contents through integration and restructuring of the original ones, at one time, highlights the design and calculation method of the basic components ,as well the modern design theory and method. After what, the new contents mainly introduce the design method of the Metallic Structure about bridge crane, gantry crane, tire crane and tower crane.

3) Update teaching contents, keeping pace with the advanced technology. Timely application of new technology, theory and method in the teaching process needs the act of actively tracking advanced technology, keeping an eye on the development trend of industry and the corporate demand for talent, additional, combining with the teaching team research results.

\section{B. Flexible use of various teaching methods}

1) Case teaching. When teaching new theory or method, taking a related project undertaken by the teaching team as a case can help students deeply understand the classroom knowledge. If the condition allows, we encourage them to participate in the project, applying what they learned in the calculation and design.
2) Strengthening of course design. Teacher selects a typical design task in his topics for the students, and let them work in groups to complete it, then compare with the teacher's one. By analyzing and summarizing the deficiencies and gap in their design, it would help them to improve.

3) On-site learning. During the course, students can practice in the related base we provide if they need. It's an effective way to deepen the understanding of the contents they learned in the production field.

4) Seminars. We encourage students attend the seminars about cranes or the related products that organized by the teaching team. These lectures are generally given by the experts in the well-known domestic companies. It has been found that it can not only improve the students' interest of the course and broaden their horizons of the industry, but also can close their distance to society.

\section{Applying a variety of techniques especially information technology actively for teaching}

1) Exploring the method of multimedia teaching and improving the classroom teaching quality. An excellent courseware is the key to develop the multimedia teaching effectively and significantly improve the quality of teaching. With the aid of school construction funds, the e-teaching plan of course named Metallic Structure was elaborated meticulously. More importantly it was applied in network education in school and a good effect was responded. When we are making an e-teaching plan, we should focus on the modern educational ideas and concentrate on the purpose to inspire students' thinking. Besides we should consider the course structure, content, process and teaching strategies from the all-round, multi-angle.

2) The combination of classroom teaching and computer aided teaching. A part of curriculum design, graduate design, engineering practice works which will be made up of threedimensional model would upload to the Internet. Students could download the works of their own interest from the department website so that the works are good reference for students own learning process. The three-dimensional model can be more intuitive to show students the specifics of the various structures and it will help to deepen learning impression as well.

\section{Optimize the teaching evaluation mechanism}

Course teaching evaluation for teachers' teaching and students' learning is bidirectional, comprehensive monitoring and evaluation of the teaching effect in the aspects of teaching and learning, to promote the continuous improvement of the teaching quality.

1) The comprehensive evaluation system for teachers. The teaching evaluation is taken by the following measures: the Education Supervision Group in the university supervises and evaluates the teaching process by attending the lectures, the mid-term students' appraisal feedback, and the final-term students' online teaching assessment, etc. Based on the above links, the course teaching team gets the teachers' evaluation information. By arranging research activities, summarizing and exchanging effective teaching 
methods and experience, the team members' teaching ability and experience can be improved constantly.

2) The reform of curriculum examination method. Aimed at the different characteristics of the theoretical teaching and the practice teaching on students' learning evaluation process, the achievement assessment measures are optimized. The evaluation is divided into three parts: the basic theory, the design class subject, and the course design. The basic theory part adopts the closed-book examinations, which mainly checks students' understanding of the basic theories, concepts, and principles. The design class subject based on the open-book examination is to assess students' practical ability. The course design adopts replying assessment. Finally, comprehensive evaluation and achievement are given by combining the three aspects of students' learning effect. The reform of curriculum examination method has greatly inspired the enthusiasm of students, improved the students' innovation ability and practical ability, and obtained the sound teaching results.

\section{CONSTRUCTION OF COURSE RESOURCES}

\section{A. Taking the integration of resources to establish various forms of practice teaching}

Around courses teaching system, the course teaching team constructs the corresponding experimental teaching system, and recognizes the practical tasks as well as the course design aspects, finally takes the practice teaching as an important means to consolidate classroom teaching and expand students' horizons.

What's more, the team actively establishes external practice base in order to combine students' theoretical study with the production practice. In accordance with the school and enterprise win-win principle, a number of practice bases have been established. The team has also signed an agreement to specify the purposes of cooperation, the target and benefits of the practice bases, the rights and obligations of both parties. At present, the practice base which includes the hoisting machinery, the construction machinery, the logistics machinery, the railway machinery and other industries, has provided students with varied content of practice.

Meanwhile, by making full use of the intramural factories and the key laboratory, they have established a perfect intramural practice base, which provides students with the conventional structure experiment, engineering practice, student research training program of practical activities.

\section{B. Making full use of information technology to enrich and improve the network resources}

With arrival of information age, a huge change has taken place in teaching model, making use of the information technology to provide students with excellent teaching resources and the autonomous learning environment has become one of the major tasks of Teachers'. On the basics of researching modern education technology, and combining with construction requirements of the excellent resource sharing curriculum, they carried out the construction of Metallic Structures courses network resources systematically.
The main contents include: the multimedia teaching courseware of Crane Metallic Structure, the threedimensional model library of the crane structure, the crane structure analysis case database, the development of new technologies of foreign crane, online exercises and Q \& A counseling website, etc. By taking advantage of these network resources students can achieve the following objectives: (1) Using multimedia courseware system to study relevant theoretical knowledge of crane Metallic Structure. (2) Intuitive understanding of the specific structure of the various types of cranes by three-dimensional model. (3) Learning the detailed process of the crane structure analysis from the specific engineering case. (4) Investigating new technologies and development trend about the crane at domestic and abroad. (5) Learning and exchanging through network and accepting teachers' guidance.

\section{CONCLUSIONS}

Based on the exploration and practice of the above several key problems, the course system and content have become more perfect, and teaching resources have achieved optimal configuration. The practice inside the school shows: the enthusiasm of students has been improved, the depth and breadth of their mastery of knowledge has been strengthened, students have achieved the expected ability to solve practical engineering problems, and teaching quality has improved steadily.

The construction of the excellent resource sharing course which requires continuously investing and long-term building is a long-term systematic project. We will take the national excellent resource sharing course as a new starting point, and aim at the first-class teaching team, first-class teaching content, first-class teaching methods, first-class teaching management to further strengthen teaching reform and improve the quality of teaching, and establish a socialoriented excellent resources sharing course.

\section{REFERENCES}

[1] Yongsheng Shen, "Several Problems in the Construction of Excellent Courses”, Research on Education Tsinghua University, No. 11,2005, pp.119-122.

[2] Yinfang Li, "Several Problems in the Construction of Excellent Courses in the Universities”, China Higher Education Research, No. 1, 2007, pp.91-93.

[3] Baoyu Huang, Guoxiong Xiang, "Analysis and Reflection on the Construction of National Excellent Courses”, China Higher Education Research, No. 9, 2007, pp72-76.

[4] Fuhai Gong, Li Wang, "Discribition about the Fine Work Course Development and Establishment of the Universities and Colleges”, Heilongjiang Researches on Higher Education, No. 1, 2004, pp.126128.

[5] Tan Xu, Changzheng Shi, "Summarization of Present Situation of Excellent Courses' Development”, China Educational Technology, No. 5, pp.53-56, 2007. 